\title{
Social entrepreneurship orientation and performance in non-profit organizations
}

\author{
Francisco do Adro ${ }^{1}$ (D) . Cristina I. Fernandes ${ }^{1,2}$ (D) Pedro M. Veiga ${ }^{3}$. \\ Sascha Kraus ${ }^{4}$ (D)
}

Accepted: 30 March 2021 / Published online: 24 April 2021

(c) The Author(s) 2021

\begin{abstract}
With the downturn in the global socioeconomic panorama, the social entrepreneurship orientation (SEO) and the social performance of non-profit organizations (NPOs) have become subject to growing levels of attention. The objective of this study is to analyze the influence of SEO on the performance of NPOs. To this end, we deployed a quantitative methodology based on the application of a survey of NPOs, which received a total of 135 valid responses. Our results demonstrate a positive effect for the dimensions of social innovation and social proactivity even while reporting no effect for the acceptance of social risks on performance. These results hold important implications across two different levels: in terms of the NPOs and policy-makers.
\end{abstract}

Keywords Non-profit organizations · Third sector · Social entrepreneurship orientation $\cdot$ Social innovation $\cdot$ Social performance

Sascha Kraus

sascha.kraus@zfke.de

Francisco do Adro

francisco.do.adro@ubi.pt

Cristina I. Fernandes

cristina.isabel.fernandes@ubi.pt

Pedro M. Veiga

motaveiga@curva-de-gauss.pt

1 Department of Management and Economics \& NECE Research Unit in Business Sciences, University of Beira Interior, Covilhã, Portugal

2 Centre for Corporate Entrepreneurship and Innovation at Loughborough University, Loughborough, UK

3 School of Education - Polytechnic Institute of Viseu \& NECE Research Unit in Business Sciences, Viseu, Portugal

4 Faculty of Economics \& Management, Free University of Bozen-Bolzano, Bolzano, Italy 


\section{Introduction}

The concept of entrepreneurship, originally applied by Richard Cantillon (1755) to the improvement of economic activities, facilitates the exchange of goods, with a focus on individual characteristics, entered the modern era through the work of Schumpeter (1934, 1939, 1942). Schumpeter highlighted the capacity for entrepreneurship to drive innovation; with the latter becoming the subject of multidisciplinary research in the literature, covering many topics ranging from the psychological, social and cultural characteristics of entrepreneurs in organizational development to the functions of organizational entrepreneurship in the development of the overall organizational performance (Arnason, 2015; Cho \& Lee, 2018; do Adro \& Fernandes, 2019; Kim, 2010). In the 1980s, entrepreneurship research focused on the psychological aspects and the behaviors of individual entrepreneurs as fundamental facets to implementing productivity, growth and economic development related processes (Drucker, 1985; Mintzberg, 1996). In recent decades, this emerging field has received increasing attention, however it still remains fragmented (Ferreira et al., 2019).

The concept of entrepreneurial orientation (EO), defined by Lurtz and Kreutzer (2017) as the processes and practices of designing the strategy that an organization deploys when engaging in new ventures or entering new markets, today stands out as a cornerstone in the literature on entrepreneurship spanning the strategic process that establishes the necessary grounds for decision-making in an approach that nurtures entrepreneurial behaviors in the business world (Morris et al., 2011; Wales et al., 2011), with such entrepreneurial processes involving a set of activities ranging from planning and analysis through to decision-making. Such processes are necessary to organizations striving to obtain their objectives and consequently gain competitive advantages (Lacerda et al., 2019; Lumpkin et al., 2013). Hence, EO reflects a critical competence to any organization.

EO thereby conveys organizational behaviors that incorporate the attributes of innovation, proactivity, competitive aggressiveness, accepting risks and autonomy but also the attitudes held towards opportunities; with these behaviors associated with entrepreneurship despite the distinctive differences in their respective mutual relationships, and ensuring EO constitutes an excellent tool for the diagnosis, development and implementation of new combinations of resources for enhancing competitiveness and facilitating the entrance into new markets (Codogni et al., 2020). The EO concept subsequently expanded into several areas like, for example, sports (Hammerschmidt et al., 2020; Nuñez-Pomar et al., 2020; Pellegrini et al., 2020), family firms (Hernández-Perlines et al., 2019; Llanos-Contreras et al., 2020), gender (Goktan \& Gupta, 2015; Santos et al., 2018), immigrant-owned businesses (José Rodríguez-Gutiérrez et al., 2020), its relation with organizational culture (Ling et al., 2020), university spin-offs (Jesús Rodríguez-Gulías et al., 2018; Migliori et al., 2019), nursing and health care (Lages et al., 2017; Marques et al., 2019) and the non-profit sector that plays a crucial role in the economy (Barrett et al., 2005; do Adro \& Leitão, 2020; Morris et al., 2011; Nuñez-Pomar et al., 2020; Pearce et al., 2010). The growth in the non-profit sector, the demands 
from governments and society in general for higher levels of efficiency, and alongside changes in the global socioeconomic panorama led to non-profit organizations (NPOs) becoming increasingly entrepreneurial, especially as regards innovation and incorporating new business models (Morris et al., 2011; Pearce et al., 2010; Sullivan Mort et al., 2003).

The majority of NPOs that display entrepreneurial behaviors do so for the following reasons: the need to generate revenues or greater internal efficiency for the financial sustainability of operations; feelings over how the demands and social needs exceed the capacity of the organization to respond; and changles in the surrounding environment that create opportunities for generating social value that did not previously exist (Dees, 2001; Morris et al., 2011; Pearce et al., 2010; Zahra et al., 2009). The desire to do more, to meet the most important social needs, doing everything possible with the existing organizational resources represent other reasons motivating entrepreneurial behaviors (Morris et al., 2011).

Despite the proliferation of research studies on EO (Kraus et al., 2019; Lumpkin et al., 2013; Martens et al., 2016; Voss et al., 2005; Wales et al., 2020), the study of EO in the non-profit sector still remains at an initial phase and lacking in scale. Nevertheless, social entrepreneurship has come in for rising levels of attention both from the academic perspective and the practical point of view (Alarifi et al., 2019; Halberstadt et al., 2020; Lurtz \& Kreutzer, 2017; Morris et al., 2011; Pearce et al., 2010; Turpin \& Shier, 2020). Thus, there is relatively little knowledge on the motivations that lead NPOs to engage in entrepreneurial behaviors (Coombes et al., 2011). The literature makes frequent reference to how NPOs, in order to better comply with their social missions, should adopt an EO (Pinheiro et al., 2020), thus a central question to the research on social entrepreneurship stems from the relationship between EO and performance, which has hitherto received little analytical study (Halberstadt et al., 2020; Wales et al., 2020). In keeping with the recommendations of the various authors that refer to the lack of empirical studies in this field (Lacerda et al., 2019; Starnawska, 2017; Syrjä et al., 2019), the objective of our study is to analyze the influence of social entrepreneurship orientation (SEO) on the performance of NPOs.

Halberstadt et al. (2020) refer to the persisting lack of clarity over whether SEO holds a positive influence over the performance of NPOs. Given that set out above, there is no doubt as to the relevance the literature attributes to an empirical study of this type. Therefore, to respond to the research question and obtain the proposed objective, we opted to apply the SEO scale proposed by Kraus et al. (2017) which spans the original EO dimensions of innovation, proactivity and risk-taking into the context of social entrepreneurship (Alarifi et al., 2019).

This research thus seeks to make various contributions. First, since according to Wales et al., (2020) the maturity of EO research and the versatility of the EO concept has led to a disperse body of knowledge, it attends on helping to centralize it on NPO sector. Secondly it serves to deepen academic knowledge in developing the social economy theory as a mandatory condition to understand entrepreneurial processes in NPOs (Ferreira et al., 2019) and how EO operates as a strategic orientation (Wales et al., 2020) in this specific sector. Third, it helps in studying the impact of each SEO component on the performance of NPOs as well as extending 
the applications of the Kraus et al., (2017) model. Fourth, this seeks to draw the attention of NPO decision-makers to the importance of SEO in their short (ongoing management) and long (strategic policy) term decision-making processes within the scope of the life of institutions. Finally, as a last contribution, this strives to open up a broader range of conceptual perspectives on EO that concentrate on how the commitment of the organization to the intensity of actions tends to drive greater risk-taking, innovation and the proactive search for business opportunities in adverse socioeconomic contexts.

\section{Literature review: Entrepreneurial orientation in NPOs}

The interest in EO concept emerged following the publication of the seminal article by Miller in 1983 (Anderson et al., 2015; Martens et al., 2016) in which the author identifies the assumption of risk and innovation as the two core facets of behavior that contribute to business success beyond proactiveness despite Mintzberg having earlier been one of the first academics to recognize the importance of EO in 1973 (Miller, 2011; Mintzberg, 1996; Wales et al., 2011). The field again expanded in the wake of the publication of the study by Covin and Slevin (1989), which has since become a classic, that refers to how EO influences the performance of organizations and their competitiveness with the scale proposed by the authors verified by its application in various subsequent research studies (Rauch et al., 2009; Wales et al., 2011). In the following decade, Lumpkin and Dess (1996) added the multidimensional facet to the EO concept with the addition of two supplementary dimensions: autonomy and aggressiveness. In keeping with advances in this field of research, the entrepreneurial ideas underwent application to efficiently expand organizational boundaries and capacities (Kim, 2010) but also to expand its scope of actions and no longer limited just to the private sector. Hence, EO, initially reserved to practices ongoing in the private sector, has spread throughout every economic structure and is today equally present in the public and non-profit sectors (Kraus et al., 2019; Nuñez-Pomar et al., 2020); and, in the latter case, very much driven by changes in the prevailing socioeconomic panorama (Morris et al., 2011).

There has been lively debate around EO especially as regards its nature and the scale of measurement (Codogni et al., 2020). Miller (1983) identified the acceptance of risk and innovation as the two core behavioral areas contributing towards business success. Accepting risk involves the act of assuming a costly commitment with an uncertain future. Innovation stems from the act of generating new combinations. Proactivity was subsequently integrated into the conceptual framework of EO to reflect the objective of organizations to be the first to obtain a client (Lieberman \& Montgomery, 1988). Hence, EO includes innovation, proactivity and the assumption of risk (Chen \& Hsu, 2013). However, the literature contains two EO constructs. The first integrates three concepts: innovation, proactiveness and risk acceptance. The second adds the facets of aggressiveness and autonomy to these (Covin \& Slevin, 1989; Lacerda et al., 2019; Miller, 2011). The weightings of each of these concepts reflects the greater or lesser extent of entrepreneurship in a particular organization alongside its EO (Lumpkin \& Dess, 1996), id est, 
the respective extent of its innovation or proactiveness. Therefore, EO provides a construct that incorporates variables covering distinctive dimensions; therefore, the majority of the measurement scales applied reflect the beliefs of their respondents. Nevertheless, when approached by more objective measures, there is evidence of the correlation between EO and organizational behaviors (Codogni et al., 2020).

While the dimensions of innovation, risk-taking and proactivity more frequently serve as the means of measuring EO (Wales et al., 2011), we did consider the appropriateness of incorporating the dimensions of competitive aggressiveness and autonomy into the equation. However, in accordance with the SEO orientations provided by Kraus et al. (2017), these latter two did not get included given that, in practice, the majority of empirical studies on EO do not deploy either competitive aggressiveness, generally subsumed under proactiveness, or autonomy (Wales et al., 2011). In sharing this opinion, Anderson et al. (2015) present a reconceptualization of EO as a multidimensional construct containing two dimensions (entrepreneurial behaviors id est innovation and proactiveness, and an attitude towards risk-taking) with both essential to the existence of EO. Furthermore, while studies interrelated with EO in the non-profit sector may adopt conceptual (Kusa, 2016), qualitative (Lurtz \& Kreutzer, 2017) or quantitative (Chen \& Hsu, 2013; Pearce et al., 2010) approaches, in all such cases, the dimensions of innovation, proactiveness and the accepting risk play central roles (Alarifi et al., 2019).

In their systematic literature review on EO in the non-profit sector, Lacerda et al. (2019) identify a sixth dimension: reciprocity, subdivided into collaboration, cooperation and partnership. Reciprocity encapsulates the capacity of NPOs to establish priorities and cooperate with their peers. Nevertheless, there is still no scale applicable to its measurement.

Hence, different perspectives on social entrepreneurship have driven the appearance of diverse definitions deriving from the respective particular focus of researchers (Kraus et al., 2017). Given the extent of the divergence in the EO definitions for the social sector and their frequent lack of clarity (Bacq \& Janssen, 2011; Dacin et al., 2010; Kraus et al., 2017), Bacq and Janssen (2011) report differences amounting to 12 definitions for social companies, 18 for social entrepreneurship, and 17 for the social entrepreneur. According to Kraus et al. (2017), the SEO definition spans the nature of the mentality applied in decision-making, behaviors and the processes that sustain the strategic design and practices in effect at organizations; their competitive posture and the management philosophies that encapsulate their entrepreneurial trends.

The question about the way in which EO emerges within the context of NPOs today represents a particularly important point of study (Morris et al., 2011) as employees' EO (Kraus et al., 2019). While in the private sector, EO closely interrelates with the senior management, in NPOs, this depends on various factors, given that the responsibilities often end up divided between the management board, the senior management, the intermediate management and members of staff in general (Beekman et al., 2012); the issues surrounding innovation, proactivity and the acceptance of risk therefore have to be adopted throughout the organization. Coombes et al. (2011) refer to how the upper management of NPOs may generate significant impacts on their organizational performance given this directly influences 
the behaviors of managers and other staff members within these institutions. Closer, Kraus et al., (2019) reinforce that when employees are really stimulated, they try to solve organizational issues, innovate in the workplace to enhance performance, facilitate intrapreneuring behavior, and create new ideas to fight competition.

Given the purpose and goals of NPOs take on particular characteristics (social mission while guaranteeing economic and financial sustainability) that do not prevail in the private, profit-making business sector, this implies that EO plays an important role as a key tool for building competitiveness in a sector traditionally more oriented towards cooperation. In fact, according to Pinheiro et al. (2020), the EO of NPOs refers to the dominant prevailing mentality of an organization that emerges in the concrete behaviors of their staff and closely bound up with the broad characteristics (mentality and behaviors) of the management board. The EO of NPOs corresponds to the behaviors they adopt as they attempt to satisfy the respective stakeholders. To this end, the role of each of the EO dimensions, irrespective of how these may exist and influence on an independent basis, interrelates with each of the others with each facet making a specific contribution towards the overall performance (Morris et al., 2011; Voss et al., 2005).

\section{Social innovation}

As innovation, a component of EO, provides the key to NPO sustainability, then the adoption of an SEO may prove beneficial to such organizations in keeping with how social innovation closely interlinks with a strong organizational commitment that favors creative ideas and processes that may result in new products, services or technological advances (Beekman et al., 2012; Tan \& Yoo, 2015).

Resource scarcity has tended to drive the creativity of social entrepreneurs as they deal with social challenges and the multiplicity and variety they pose ensure managers require a varied range of tools to bring about innovation (Alarifi et al., 2019).

In the third sector, innovation may assist in NPOs providing better services to their communities (Beekman et al., 2012). Based on a systematic literature review and the qualitative analysis of 24 semi-structured interviews, García-flores and Martos (2019) propose the following definition of social innovation (SI): practices or initiatives undertaken by the community that, based on the products, services or models that they manage, or through the processes developed to obtain their goals, produce solutions that provide a better response, in an alternative and creative manner, to the social problems or needs. Therefore, the creation of social value through SI and the design of strategies are core to the social entrepreneurship process. SI constitutes a fundamental aspect of social entrepreneurship (Choi \& Majumdar, 2014; Nandan et al., 2019) and results from a combination of resources (Foroudi et al., 2020). According to Piccarozzi (2017). SI very closely interrelates with sustainability and the actions taken to achieve this need to incorporate those conceptual measures even while Eichler and Schwarz (2019) point out how little is known about which type of sustainable objectives SI best leverages. However, academics do agree in stating that innovation helps in improving the efficiency and performance of NPOs enabling them to render better quality services to their users (Suh et al., 2018). The study by Nuñez-Pomar et al. (2020) identifies innovation as a core factor in returning good levels of performance. Given that set out above, 
innovation emerges with a critical role for NPOs experiencing pressure to adopt methods traditionally applied only to the profit-making sector (Dover \& Lawrence, 2012; Suh et al., 2018) due to the consequences of a downturn in state funding (Roque \& Rocha, 2019).

Hence, we arrive at our first hypothesis:

H1: Social innovation generates a positive influence on the performance of NPOs

\section{Social proactivity}

Proactivity is generally interpreted as if dealing with the reactiveness to an occasional situation, which may take place when organizations respond to dilemmas that threaten their survival; however, being truly proactive involves thinking about the ways in which organizations overcome their structural barriers and prosper and take effective decisions (Corsini et al., 2018; Turpin \& Shier, 2020). Thus, proactivity refers to the active searching for opportunities, pre-empting demand, being the first to take an attitude and differing from innovation in how the latter incorporates something new, such as an invention, for example. Proactivity more simply involves the implementation of new measures that are imitations and replications in their overwhelming majority (Alarifi et al., 2019; Pearce et al., 2010). Proactive organization generally deploy information and knowledge to identify the opportunities arising and to gain competitive advantages over their peers (Lumpkin \& Dees, 2001; Rauch et al., 2009). Some authors (Chen \& Hsu, 2013) have attempted to ascertain whether there is an inverted U-shaped relationship between proactive behaviors and levels of NPO performance, although there has been no verification of the hypothesis that excessive proactivity might be harmful to performance. The empirical study by Kim et al. (2013) on the third sector in South Korea concludes that proactivity returns a positive impact on NPO performance. In turn, Turpin and Shier (2020) identify the need for further study to understand the role of proactivity in the EO of NPOs as well as the ways in which these aspects require interrelating with the assumption of risk and SI.

We thus reach our second hypothesis:

H2: Social proactivity generates a positive influence on the performance of NPOs

\section{Acceptance of social risks}

To any organization, assuming risks reflects the willingness to invest significant resources in entering unknown or uncertain markets, ignoring the possible consequences (Alarifi et al., 2019; Chen \& Hsu, 2013). Therefore, the acceptance of risks involves the capacity to act beyond the usual practices and accepted norms (Pearce et al., 2010), with a level of moderation proposed by Begley and Boyd (1987), who find that the organizations with the best levels of performance are those that adopt policies with moderate levels of risk.

In the non-profit sector, the acceptance of risks may also be non-financial in nature (Alarifi et al., 2019) and more problematic than in the for-profit sector (Tan \& Yoo, 
2015) and reflected in the issues surrounding reputation when granting or not granting support to interested parties (clients, communities, etc.) and holding repercussions for compliance with the social mission. Similarly, compliance with the social mission may involve incurring substantial financial losses (Alarifi et al., 2019). As their mission, NPO entrepreneurs accept the measuring of the potential risks and taking decisions according to these measurement results (Turpin \& Shier, 2020).

The study by Rauch et al. (2009) points to EO returning a positive impact on the (especially non-financial) performance aspects of organizations. Taking into account how financial perceptions and non-financial performance interlink, in cases of success in assuming risks interrelated with social entrepreneurship, the returns beyond the social dimension may also generate financial gains (Halberstadt et al., 2020). However, following their study, Hong and Cho (2012) state they do not encounter any significant and positive relationship between the EO and the social performance of NPOs.

Therefore, we may put forward our third hypothesis:

H3: Accepting social risks generates a positive influence on the performance of NPOS

Figure 1 presents our research model.

\section{Research and data analysis methodology}

\section{Questionnaire and data collection}

This research applies a correlational design to examine the relationships between EO and the performance of NPOs. In order to test these relationships, we drafted

Fig. 1 Research model

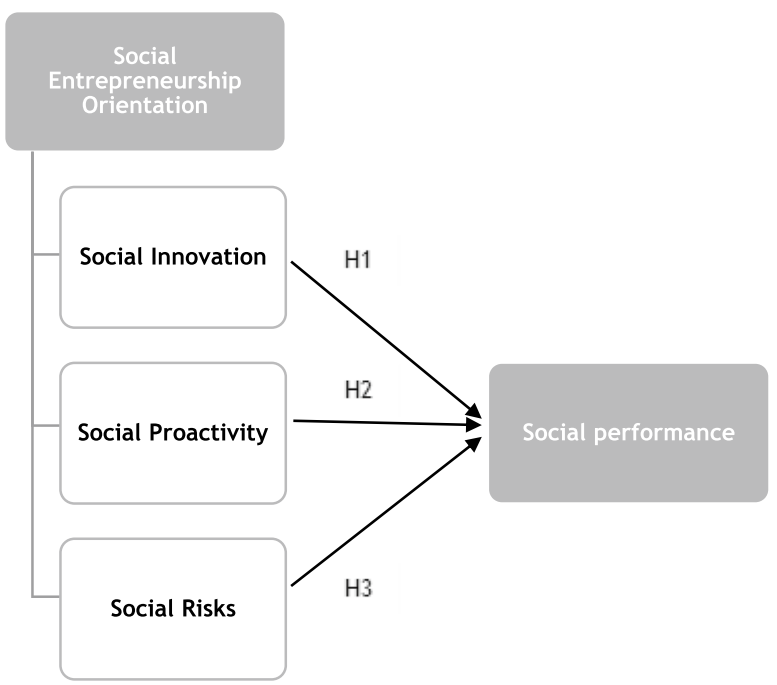


the research instrument and developed measurement scales based on a review of earlier research, such as the Kraus et al. (2017) model.

The questionnaire measurement scales consist of items that depict the knowledge and opinions of the interviewees about the EO practices and social performance. In order to construct the questionnaire and similar to other authors (Pinheiro et al., 2020), we applied existing and already validated scales, translated and adapted for the purpose of the present study. We discuss all of the items for measuring these variables and the respective scales below.

The data collection process was severely limited by the health pandemic that has buffeted Portugal since March 2020. Initially due for launch at the beginning of April, collection only began with the progressive end of the first period of lockdown. If in periods characterized as "normal", institutions relegate responding to questionnaires down to a second or third priority, the health crisis still further hindered the collection process given the clear additional efforts undertaken by the NPOs in order to control the pandemic within scope of their own organizations.

We submitted the questionnaire via e-mail and available through the Google Forms application to the social economy organizations in mainland Portugal and the Autonomous Regions of the Azores and Madeira between 1 June and 30 September 2020. We first sent the questionnaire to CNIS - the National Confederation of Solidarity Institutions and the respective UDIPSSs and URIPSSs - the District and Regional Unions, the Portuguese Union of Charities and the Portuguese Union of Mutual Associations following prior telephone contact to present the study and request the sending of the questionnaire to their respective associated members (3,653 institutions with 3,004 affiliated to CNIS according to its 2019 management report even though this number is subject to frequent variation). Contacts also included the António Sérgio Cooperative for the Social Economy given this entity is responsible for updating the list of all NPOs in Portugal (Pinheiro et al., 2020). In a second phase (July and August), we contacted, firstly by telephone and then by e-mail, the coordinating entities of the CLDS4G program present in 232 of the 278 councils on mainland Portugal. Finally (in September), we established contact with the municipal social network that includes 100 councils located from the north to the south of the country as well as the Autonomous Regions of the Azores and Madeira. This social network is a national program set up in 1997 in order to empower the social actors of councils and better combat poverty, social exclusion while fostering social development (Presidência do Conselho de Ministros, 1997).

Through this diversified strategy, and given that not all institutions maintain affiliations to either confederations or federations, we sought to contact the population of 5647 IPSSs - Private Social Solidarity Institutions or their equivalent existing in Portugal according to the report "Importância económica e social das IPSS em Portugal" published in December 2018 by CNIS (Mendes, 2018).

The final sample was 135 NPOs disseminated throughout the national territory, of different sizes and providing a varied range of social responses (infancy and youth, health and disabilities, elderly persons and others). 


\section{Measurements}

\section{Dependent variables}

The construct approaching social performance came from Sanzo et al. (2015) and includes a Likert scale ranging from 1 to 7 (from "not important" to "very important"), with 16 items (Annex 7) then subdivided into three different dimensions:

1. Internal marketing, including aspects such as human resource policies and training in the organization, the appropriateness of the tasks to the capacities of collaborators, internal communication and listening to employees (10 items, Cronbach's Alpha =0.926);

2. Benefits from partnerships, particularly sounding out stakeholders by the organization (3 items, Cronbach's Alpha=0.791);

3. Mission compliance regarding the satisfaction of the requests and expectations of organizational stakeholders (3 items, Cronbach's Alpha =0.869).

The items making up each of these factors (Internal marketing, Partnership benefits, Mission compliance) display considerable levels of reliability and internal consistency. The second order construct referring to social performance returns extremely high levels of reliability and internal consistency (Cronbach's Alpha =0.939).

For each dimension and for the overall social performance, we calculated a score corresponding to the average for the items.

\section{Independent variables}

Control variables The characterization of the institutions took into account diverse aspects, such as: the location (NUT2), the type of social response, the number of employees (directly employed or contracted/outsourced staff), the number of volunteers, the number of users as well as whether or not the organization runs a quality management system.

(Social) Entrepreneurial orientation To operationally apply the SEO variables (Table 1), we adopted the scale put forward by Kraus et al. (2017). Within the scope of tailoring the scale to the specific characteristics of these NPOs, as well as to better harmonize the contents, we replaced the terms "company, foundation, institution, organization" by the word "organization". This also substituted the words "user" or "beneficiary" with the term "user" in order to adopt the terminology of the Institute of Social Security included in all the cooperation agreements signed between the supervisory authority and the organizations in the sector. This correspondingly substituted the expression "target areas" for "target public". Following these adaptations, we sent the questionnaire, with its measurements adopting a 4-point Likert scale, to the NPOs. The nine questions (Annex Table 6) break down into three sub-dimensions: 


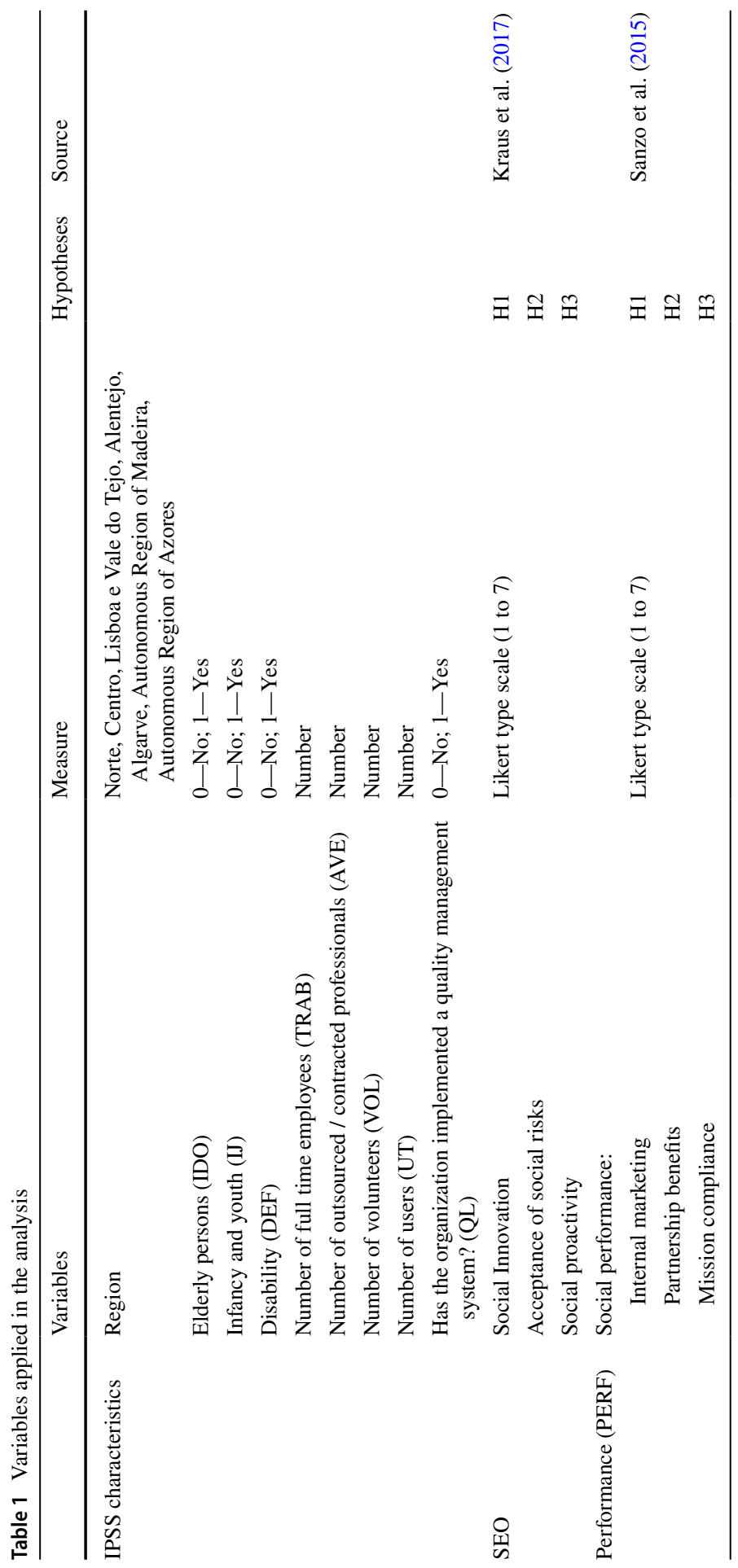


1. Social innovation: "Social innovation is important to our organization; our organization frequently suggests new ideas..."” (3 items, Cronbach's Alpha =0.775),

2. Acceptance of social risks: "We are not afraid to run risks...; risky action is necessary in order to obtain the social mission..." (3 items, Cronbach's Alpha=0.794),

3. Social proactivity: "We aim to be in the vanguard...; Normally, we begin the actions that the others copy..." (3 items, Cronbach's Alpha=0.796).

\section{Data analysis}

In order to describe the IPSS sample, we calculated the descriptive statistics (frequencies, averages and standard deviations) of the variables included in the research study. In order to evaluate the NPO characteristics and the EO dimensions of the social performance variables, and given there are correlations among the dependent variables, we applied multivariate analysis of covariance (MANCOVA). Hair et al. (2010) recommend the utilization of Pillai's trace as this provides the most potent statistics for samples in which the categorical variables are small in scale and different. Whenever identifying variables with statistically significant impacts on the dependent variables, we undertook analysis of covariance (ANCOVA) for each of the dependent variables and their respective multiple linear regression models.

We analyzed all the data through recourse to IBM-SPSS software version 27.0 (IBM Corporation, New York, USA).

\section{Results}

\section{Descriptive statistics}

Table 2 contains the characteristics of the 135 institutions included in the study. The predominant locations correspond to the regions Centro (47.4\%), Norte (18.5\%) and Lisboa e Vale do Tejo (18.5\%). In terms of the social responses provided by the organizations, $45.2 \%$ and $11.9 \%$ of organizations deal with infancy and youth and disability issues respectively. The institutions employ an average of $60.1 \pm 77.6$ full time members of staff and cater for an average of $693.7 \pm 2458.4$ users.

\section{Testing the hypotheses and discussion}

In order to test our hypotheses, we calculated a MANCOVA (Table 3) followed by four ANCOVA tests (Table 4 in the Appendix). 
As regards the characteristics of these organizations, we verify how the MANCOVA tests report that the control variables response to disability (Pillai's Trace $=0.07 ; \mathrm{F}(3,115)=2.76 ; \mathrm{p}<0.05$ ), number of volunteers (Pillai's Trace $=0.09 ; \mathrm{F}(3,115)=4.00 ; \mathrm{p}<0.05)$ and the number of organization users (Pillai's Trace $=0.10 ; \mathrm{F}(3,115)=4.05 ; \mathrm{p}<0.01)$ hold a significant impact on the variables making up social performance (Table 1).

In turn, ANCOVA registers how the provision of social responses to disabilities generates a statistically significant impact on the performance of internal marketing $(\mathrm{F}(1,117)=3.87 ; \mathrm{p}<0.05)$ as does mission compliance $(\mathrm{F}(1,117)=3.91 ; \mathrm{p}<0,05)$ on the performance of partnership benefits $(\mathrm{F}(1,117)=3.92$; $\mathrm{p}<0.05)$ and on total performance $(\mathrm{F}(1,117)=3.99 ; \mathrm{p}<0.05)$. The organizations rendering social response to infancy and youth issue return median scores for internal marketing (with responses: 5.53; without responses: 4.84), partnership benefits (with responses: 5.87; without responses: 5.08), mission compliance (with responses: 5.85; without responses: 5.55) and social performance (with responses: 5.65; without responses: 4.95) and thereby significantly high than NPOs that do not provide social responses to infancy and youth (Table 5 in the Appendix). The number of volunteers ensures a negative impact on the internal marketing performance while the number of users generates a positive impact on internal marketing, partnership benefits, mission compliance and social performance.

As regards the SEO dimensions, the results detail how social innovation (Pillai's Trace $=0.11 ; \mathrm{F}(3,115)=4.23 ; \mathrm{p}<0.01)$ and social proactivity (Pillai's Trace $=0.14$; $\mathrm{F}(3,115)=6.37 ; \mathrm{p}<0.001)$ cause a statistically significant impact on the social performance variables in overall terms (Table 1). Based on ANCOVA, we may state that both social innovation and social proactivity return statistically significant positive impacts on the internal marketing performance (Social Innovation: $\mathrm{F}(1,117)=6.74 ; \mathrm{p}<0.05$; Social proactivity: $\mathrm{F}(1,117)=19.04 ; \mathrm{p}<0.001)$, as well as on mission compliance (Social Innovation: $\mathrm{F}(1,117)=10.41 ; \mathrm{p}<0.01$; Social proactivity: $\mathrm{F}(1,117)=12.43 ; \mathrm{p}<0.01)$ and on the performance of partnership benefits (Social Innovation: $\mathrm{F}(1,117)=7.77 ; \mathrm{p}<0.01$; Social proactivity: $\mathrm{F}(1,117)=8.26$; $\mathrm{p}<0.01$ ) and on total performance (Social Innovation: $F(1,117)=5.94 ; p<0.05$; Social proactivity: $\mathrm{F}(1,117)=17.95 ; \mathrm{p}<0.001)$. The variables producing the strongest impact on the set of variables for social performance are those encapsulating SEO, social proactivity $\left(\eta_{p}^{2}=0.143\right)$ and social innovation $\left(\eta_{p}^{2}=0.105\right)$ (Table 5 in the Appendix).

We may therefore affirm the validity of our hypotheses $\mathrm{H} 1$ and $\mathrm{H} 2$. These results are consistent with the conclusions of some of the authors focusing on this theme. Earlier studies (Halberstadt et al., 2020; Nuñez-Pomar et al., 2020; Pearce et al., 2010; Pinheiro et al., 2020) demonstrate that organizations that act with a defined EO turn in better levels of performance than others and thereby establishing a positive relationship between EO and social performance. Khan and Bashir (2020), through their study on the Pakistani third sector, report how EO generates a positive effect on organizational performance and that beyond being a valuable intangible asset, this represents a consistent strategic orientation. The meta-analysis by Rauch et al. (2009), which examines data from 53 samples, sets out strong evidence of a positive and moderately strong 


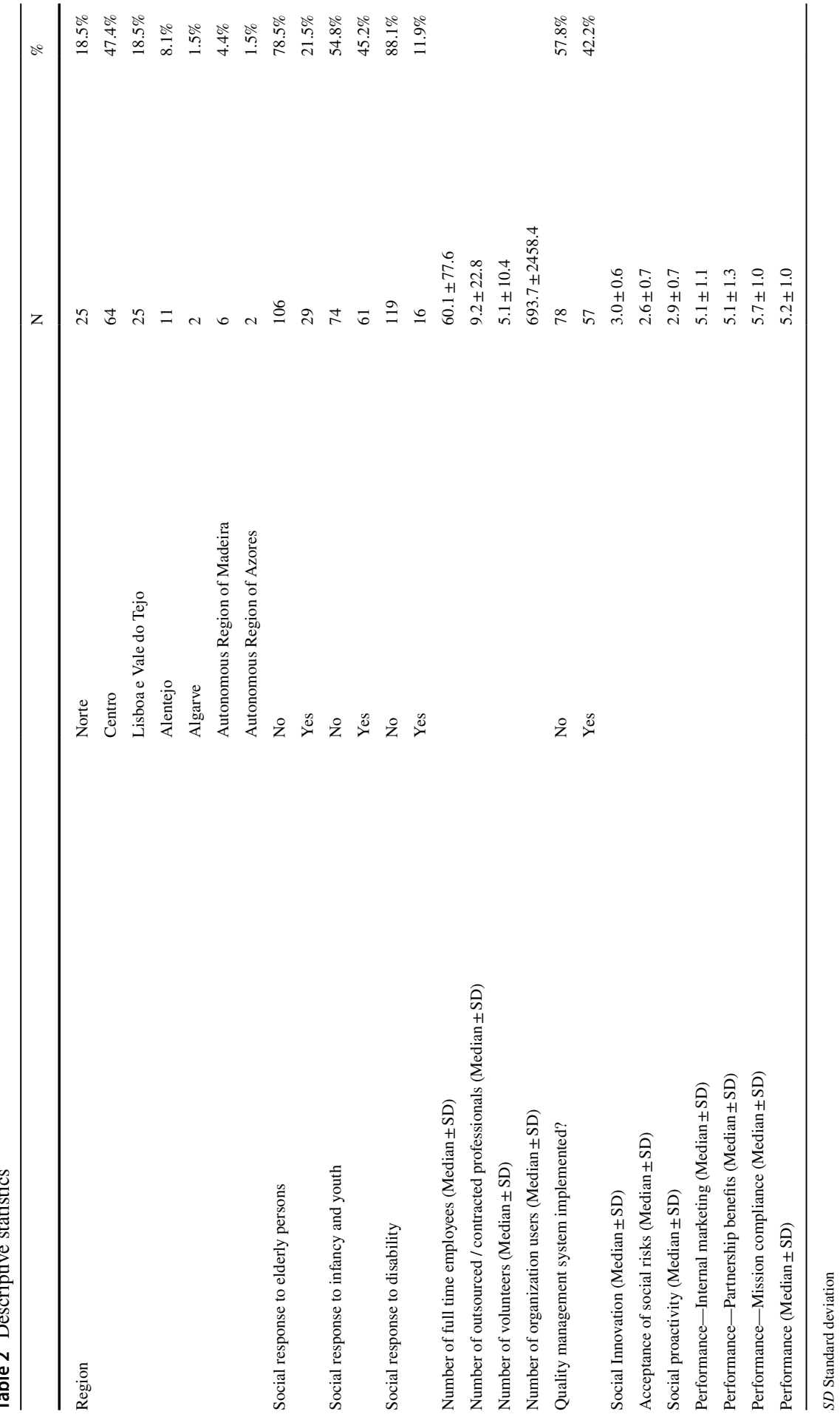


relationship between EO and organizational performance. One of the conclusions to the study by Cho and Lee (2018) identifies how progressive innovation favors better non-financial performance standards.

As regards $\mathrm{H} 3$, in this case, there is no reported effect (Pillai's Trace $=0.01$; $\mathrm{F}(3,115)=0.36 ; \mathrm{p}=0.779)$. Despite the consistency with the results of Alarifi et al. (2019), and also with the alluded by Kraus et al. (2019) who refers that the effect of the SEO sub-dimensions could vary, this finding emerges somewhat unexpectedly given that the assumption of risks represents a central component of both innovation and proactivity (Kim, 2010). However, Beekman et al. (2012) state that at times when creativity and innovation are most necessary, NPOs tend to be more conservative about fund raising, which reflects a certain failing to accept risks. The research by Kim (2010) indicates how proactivity, innovation and risk-taking positively interrelate with performance; the study by Syrjä et al. (2019) on the Finnish social sector conveys how NPOs, despite their risk adverse nature, are willing to self-correct, be proactive and innovative in the search for new revenue streams and in resolving social problems and that the commitment of senior management to the cause of the organization ensures both their resilience and their compliance with their social missions. This latter result may identify a shortcoming in the SEO component of Portuguese NPOs even while this needs to be subject to future confirmation especially because in undertaking the process of designing the Kraus et al. (2017) measurement scale, 16 of the 18 respondents (almost exclusively from Europe and the United States, which deepens the appropriateness of the model to local NPOs) consider that risk-taking requires inclusion on the grounds of being an essential component.

\section{Implications}

The SEO impact on the performance organizations is positive to the extent this contributes to their growth and sustainability over the long term (Syrjä et al., 2019).

On the grounds that NPOs fall under pressure to perform financial roles in order to survive, but also out of responsibility for complying with their social missions, to satisfy their associates as well as their multiplicity of stakeholders, this provides them with a more complete and complex framework than in the private sector given that this is not only and exclusively about developing a new product or service but rather taking into consideration the meeting of social needs. Voss et al. (2005) put forward evidence that when the interactions between the influence of stakeholders and the SEO associated behaviors are transparent, managers engage in developing reciprocal strategic relationships that strengthen these behaviors. On the contrary, when this relationship is less clear, managers spend more time dealing with the more diverse and complex requests from other stakeholders. Hence, the effects of entrepreneurial practices on organizational performance may take on various different natures and susceptible to measurement by financial and operating (non-financial) indicators but also according to internal scales (members of staff) and external scales 


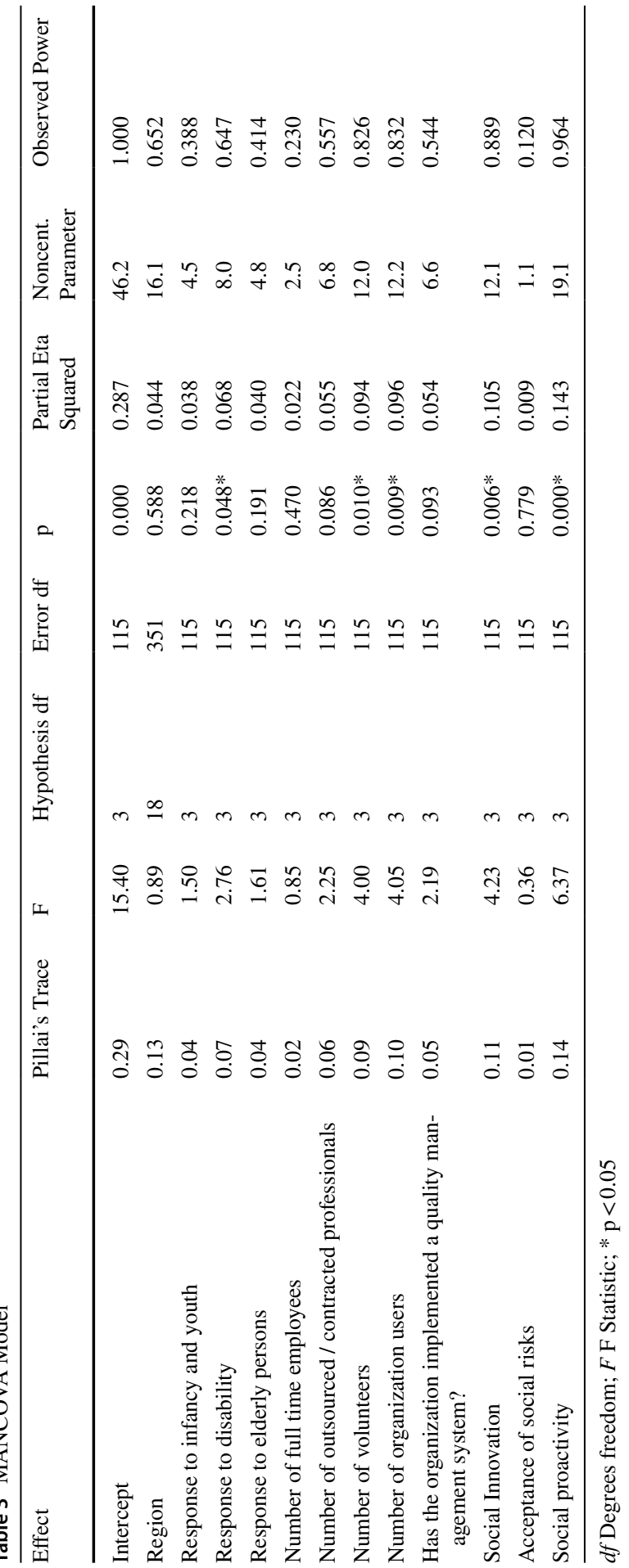


(clients, suppliers, etc.) (Kim, 2010). Performance levels rise in keeping with how proactive and innovative behaviors and the taking of risks enable organizations to create new markets, launch new products and services, thereby modifying their value propositions to clients while bringing about significant reductions to their costs (Coombes et al., 2011).

Hence, NPO senior managers need to take up more proactive stances and not shy away from assuming risks whether in terms of the strategic policy (long term) or in the current management (short term) in order to raise the levels of organizational performance. This may involve establishing more innovation favorable environments, less formal and more flexible but also through implementing quotas that are not merely symbolic, designing and implementing new services and /or commercial activities, the diversification of revenues through attracting new sources of income and support and as well as sharing their resources, such as through setting up central procurement systems, especially at smaller scale NPOs, in order to generate economies of scale and gaining a greater weighting in negotiations over the supply of goods and services. As regards this latter point on central procurement systems, this recommends advancing in accordance with the specific wishes of the NPOs and not due to the actions / influences of federations or unions as observations of past situations demonstrated that they are not always able to guarantee the best quality /price relationship, as was the case with the protocol signed between GALP Energia and CNIS in 2013 that ended guaranteeing the supply of electricity at a higher price than those negotiated individually by some NPOs.

With the increase in competition over sources of financing, this analysis provides a relevant tool both for private financiers and for policy decision-makers when considering whether support should go to those NPOs with higher or lower levels of SEO as one means of ensuring its efficient application.

This study also enables a better understanding of the relationship between SEO and performance in other countries that culturally resemble Portugal, for example countries that were formerly its colonies or Spain, with the latter's non-profit sector displaying similarities with Portugal with the founding of the Santas Casas da Misericórdia charitable institutions in the late fifteenth century in Portugal even while in the current context both the Portuguese and Spanish institutions operate under different organizational and legal frameworks (Ruano et al., 2020).

\section{Final considerations, limitations and future lines of research}

The objective of this study involved analyzing the influence of SEO, and especially in terms of each of its components, on the performance of NPOs in order to scrutinize which factors of entrepreneurial orientation influence NPOs' performance.

This research presents new dimensions in a field that still remains relatively unstudied: the relationship between EO, a concept initially oriented for the profit-making sector but subsequently extended to include the social economy, 
and the performance of the non-profit sector in Portugal. After having identified the SEO factors (social innovation, social proactivity and acceptance of social risks), they were subject to testing through recourse to quantitative data gathered from 135 NPOs located across mainland and island Portugal through an online questionnaire. The results, in their majority consistent with earlier research, demonstrate that innovation, proactivity and the assumption of risk, although only to a lesser extent with this latter factor, return a positive impact on the performance of these institutions.

Similar to other research studies, our results display their own limitations with one due to the data collection process having taken place over one timeframe, in the midst of the pandemic, which substantially hindered the process and preventing the study from being more representative. Thus, future studies might verify these results. Another limitation derives from the poor level of response in terms of data that might enable an evaluation of the financial performance to the extent of preventing analysis of its respective impact on SEO.

We may also affirm that there remains scope for future research on EO in the third sector especially as regards financial performance because while the creation of social value with a relevant impact constitutes the core objective of NPOs, financial viability also plays a crucial role given the extent of its contribution towards achieving this objective. Earlier studies in this field (Coombes et al., 2011; Halberstadt et al., 2020) reveal how EO may not actually impact on the financial performance all the while Kim et al. (2013) report a positive impact for innovation on the financial performance of NPOs in Kenya. Hence, there is no consensus on this issue. Furthermore, undertaking research on this theme represents a complicated task in the majority of countries due to the difficulties in obtaining objective means of measurement. The present study also verified certain difficulties on behalf of the NPOs in providing data on this factor of analysis.

In keeping with the position of Alarifi et al. (2019), this also suggests the potential need to redefine the concept of accepting risk in the social sector given that, contrary to the private sector, such institutions rarely face the prospect of bankruptcy or failure given that central or local government financial support, in keeping with the weighting of NPOs in the local economy, both in terms of employment and the sourcing of goods and services from local producers and suppliers, normally take on part or all of such liabilities in order to guarantee organizational continuity. This may additionally provide an explanation for the low levels of risk assumed across the sector.

Another crucial line for future research, from our perspective, involves the design of a measurement scale for the dimension of reciprocity as identified by Lacerda et al. (2019). 


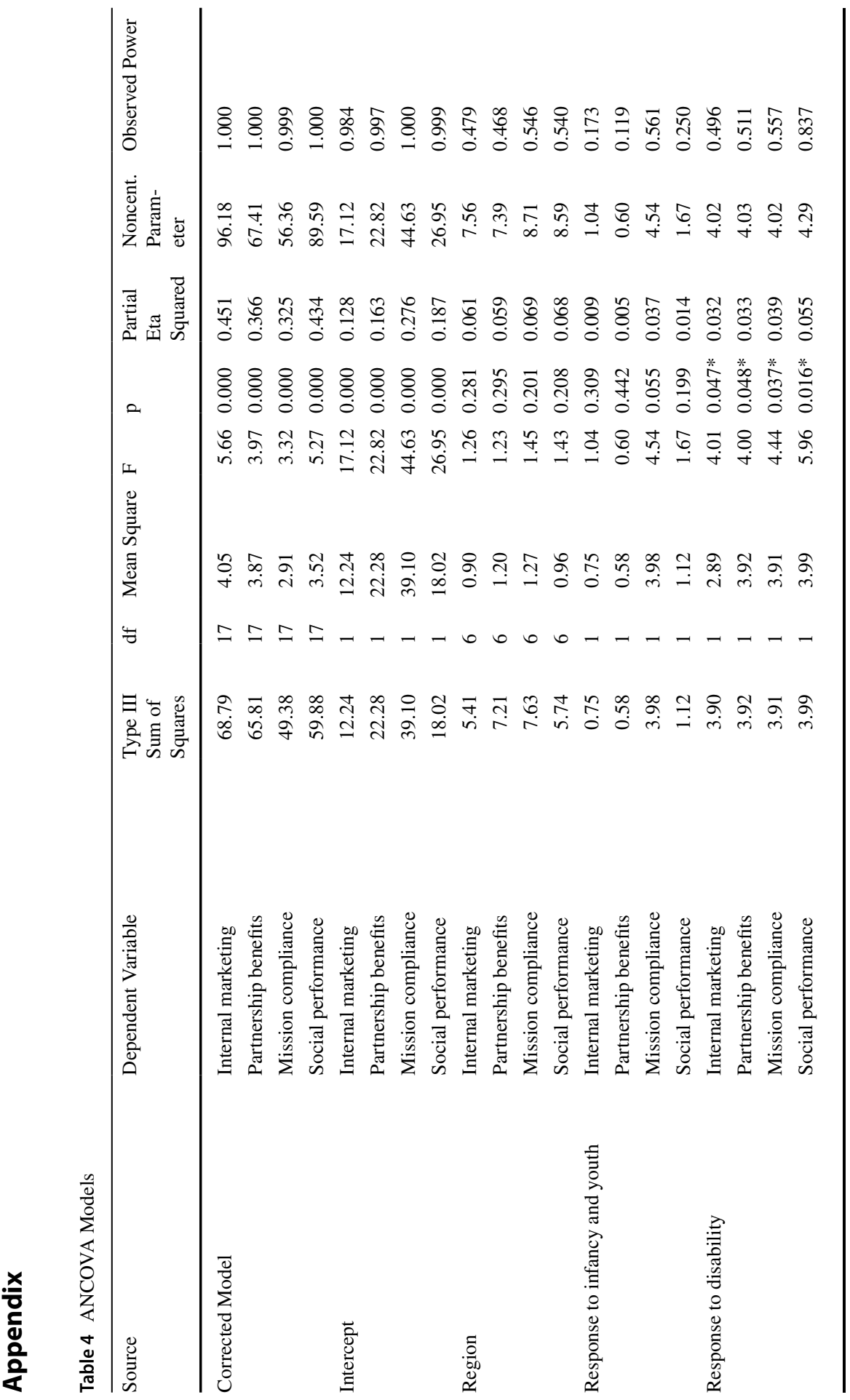




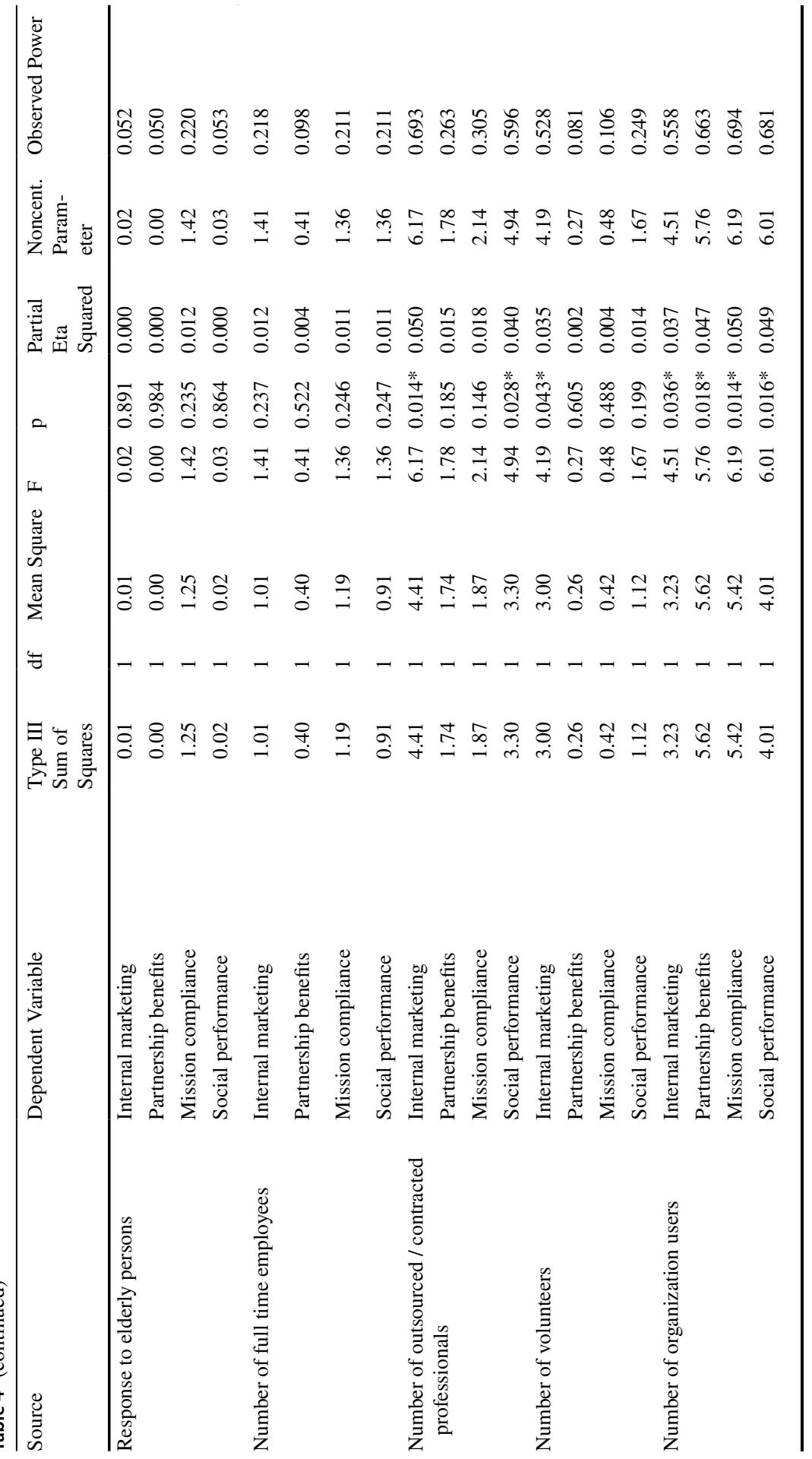




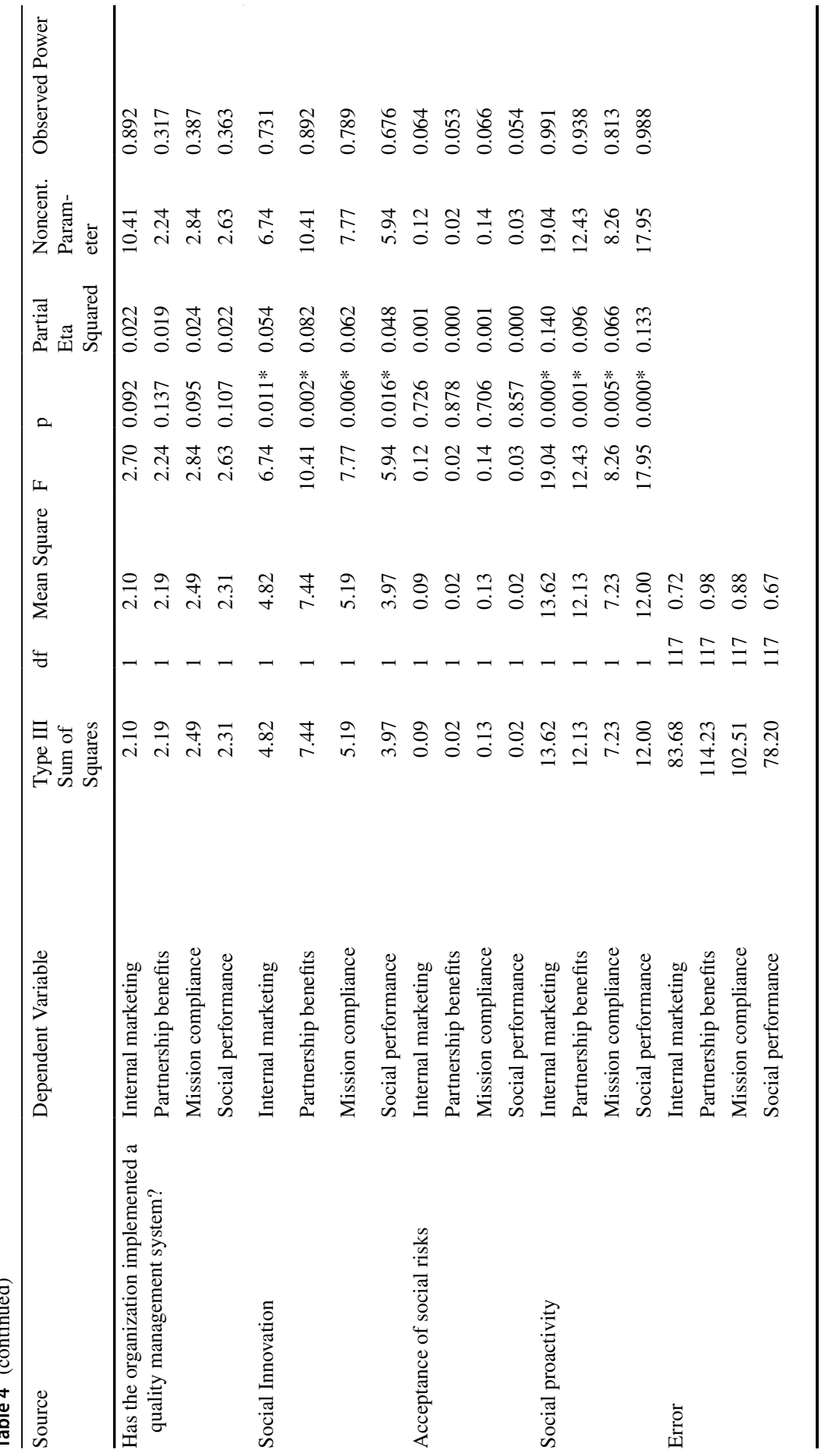




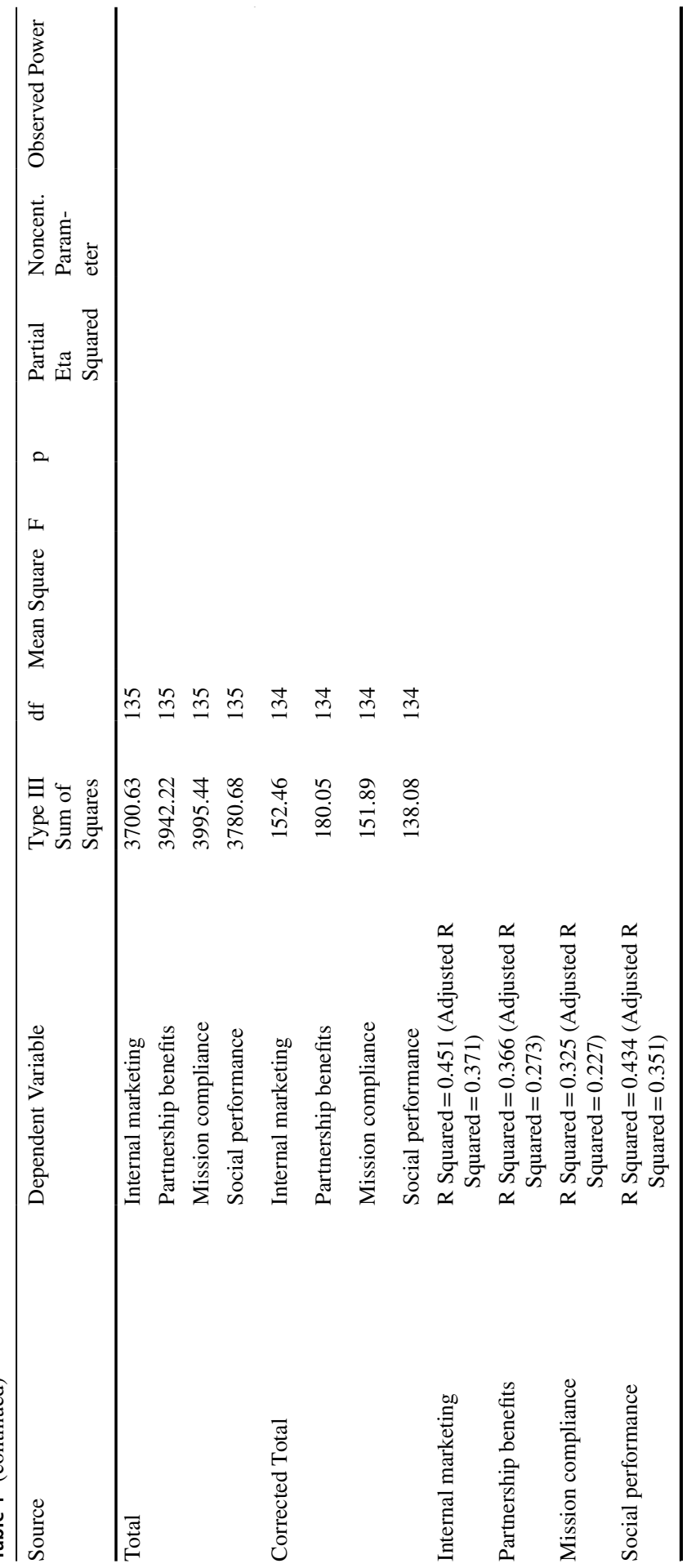


Table 5 Adjusted mean values after accounting for the effects of covariates

\begin{tabular}{|c|c|c|c|c|c|}
\hline \multirow[t]{2}{*}{ Dependent variables } & & \multirow[t]{2}{*}{ Mean } & \multirow[t]{2}{*}{ SE } & \multicolumn{2}{|c|}{$95 \% \mathrm{CI}$} \\
\hline & & & & LB & UB \\
\hline \multirow[t]{2}{*}{ Internal marketing } & Without response to infancy and youth & 4.84 & 0.16 & 4.52 & 5.15 \\
\hline & With response to infancy and youth & 5.53 & 0.26 & 5.01 & 6.05 \\
\hline \multirow[t]{2}{*}{ Partnership benefits } & Without response to infancy and youth & 5.08 & 0.18 & 4.71 & 5.44 \\
\hline & With response to infancy and youth & 5.87 & 0.31 & 5.26 & 6.48 \\
\hline \multirow[t]{2}{*}{ Mission compliance } & Without response to infancy and youth & 5.21 & 0.17 & 4.86 & 5.55 \\
\hline & With response to infancy and youth & 5.85 & 0.29 & 5.28 & 6.43 \\
\hline \multirow[t]{2}{*}{ Social performance } & Without response to infancy and youth & 4.95 & 0.15 & 4.65 & 5.25 \\
\hline & With response to infancy and youth & 5.65 & 0.25 & 5.15 & 6.16 \\
\hline
\end{tabular}

$S E$ Standard error; $C I$ Confidence interval; $L B$ Lower bound; $U B$ Upper bound

Table 6 Measuring entrepreneurial orientation

\begin{tabular}{|c|c|}
\hline Dimensions & Indicators \\
\hline Social Innovation & $\begin{array}{l}\text { 1. Social Innovation is important to our organization } \\
\text { 2. We invest strongly in developing new ways of boosting our social impact } \\
\text { or serving our users } \\
\text { 3. In our organization, we frequently suggest new ideas for dealing with } \\
\text { social problems }\end{array}$ \\
\hline Acceptance of Social Risks & $\begin{array}{l}\text { 1. We are not afraid of accepting substantial risks in order to serve our } \\
\text { social objective } \\
\text { 2. Bold actions are necessary to obtaining the social mission of our organi- } \\
\text { zation } \\
\text { 3. We avoid taking a cautious line of action whenever social opportunities } \\
\text { might get missed by taking such an approach }\end{array}$ \\
\hline Social proactivity & $\begin{array}{l}\text { 1. We aim to be in the vanguard for making the world a better place } \\
\text { 2. Our organization has a strong trend to be in front of others in its approach } \\
\text { to its social mission } \\
\text { 3. Normally, we begin actions that other social entrepreneurs / social } \\
\text { organizations copy }\end{array}$ \\
\hline
\end{tabular}

Source: Based on Kraus et al. (2017) 
Table 7 Measuring performance (social performance)

\begin{tabular}{|c|c|}
\hline Dimensions & Indicators \\
\hline Internal marketing & $\begin{array}{l}\text { 1. The organization emphasises its understanding of the needs and expectations of } \\
\text { employees } \\
\text { 2. The organization regularly evaluates the workplace satisfaction of its employees } \\
\text { 3. The organization knows the human resource policies of other organizations } \\
\text { 4. The organization knows about the labour market situation in its sector of activity } \\
\text { 5. Employees report their problems whenever affecting their performance } \\
\text { 6. Senior management regularly collects information on the problems employees } \\
\text { encounter in implementing their tasks } \\
\text { 7. The work is appropriate to the professional capacities of employees } \\
\text { 8. The organization's human resource policy takes into account the professional } \\
\text { development of employees } \\
\text { 9. The organization's human resource policy actively seeks to improve the working } \\
\text { conditions } \\
\text { 10. The organization runs a staff training program }\end{array}$ \\
\hline Partnership benefits & $\begin{array}{l}\text { 1. Satisfying the requests, needs and expectations of users } \\
\text { 2. Satisfying the expectations of donors as regards the usage of their financing by } \\
\text { the organization } \\
\text { 3. Satisfying the members of staff }\end{array}$ \\
\hline Mission compliance & $\begin{array}{l}\text { 1. Achieving the mission and objectives of the organization } \\
\text { 2. Satisfying the requests, needs and expectations of users } \\
\text { 3. Satisfying the expectations of donors as regards the usage of their financing by } \\
\text { the organization }\end{array}$ \\
\hline
\end{tabular}

Source: Based on Sanzo et al. (2015)

Acknowledgments This research was supported by The Portuguese Foundation for Science and Technology (Grants and NECE-UIDB/04630/2020)

Funding Open access funding provided by Libera Università di Bolzano within the CRUI-CARE Agreement.

Open Access This article is licensed under a Creative Commons Attribution 4.0 International License, which permits use, sharing, adaptation, distribution and reproduction in any medium or format, as long as you give appropriate credit to the original author(s) and the source, provide a link to the Creative Commons licence, and indicate if changes were made. The images or other third party material in this article are included in the article's Creative Commons licence, unless indicated otherwise in a credit line to the material. If material is not included in the article's Creative Commons licence and your intended use is not permitted by statutory regulation or exceeds the permitted use, you will need to obtain permission directly from the copyright holder. To view a copy of this licence, visit http://creativecommons.org/licen ses/by/4.0/.

\section{References}

Alarifi, G., Robson, P., \& Kromidha, E. (2019). The Manifestation of entrepreneurial orientation in the social entrepreneurship context. Journal of Social Entrepreneurship, 10(3), 307-327. https://doi. org/10.1080/19420676.2018.1541015. 
Anderson, B. S., Kreiser, P. M., \& Donald, F. (2015). Reconceptualizing entrepreneurial orientation. Strategic Management Journal, 36(10), 1579-1596. https://doi.org/10.1002/smj.2298.

Arnason, J. P. (2015). Theorizing capitalism: Classical foundations and contemporary innovations. European Journal of Social Theory, 18(4), 351-367. https://doi.org/10.1177/1368431015 589153.

Bacq, S., \& Janssen, F. (2011). The multiple faces of social entrepreneurship : A review of definitional issues based on geographical and thematic criteria. Entrepreneurship \& Regional Development, 23(5-6), 373-403. https://doi.org/10.1080/08985626.2011.577242.

Barrett, H., Balloun, J. L., \& Weinstein, A. (2005). The impact of creativity on performance in nonprofits. International Journal of Non-profit and Voluntary Sector Marketing, 10(4), 213-223. https://doi.org/10.1002/nvsm.25.

Beekman, A. V., Steiner, S., \& Wasserman, M. E. (2012). Where innovation does a world of good: Entrepreneurial orientation and innovative outcomes in non-profit organizations. Journal of Strategic Innovation and Sustainability, 8(2), 22-36.

Begley, T. M., \& Boyd, D. P. (1987). Psychological characteristics associated with performence in entrepreneurial firms and smaller businesses. Journal of Business Venturing, 2(1), 79-93. https://doi.org/ 10.1016/0883-9026(87)90020-6.

Cantillon, R. (1755). Essai sur la nature du commerce en général. M., Thornton (Ed.). Mises Institute.

Chen, H. L., \& Hsu, C. (2013). Entrepreneurial orientation and firm performance in non-profit service organizations : contingent effect of market orientation, 2069. https://doi.org/10.1080/02642069. 2011.622372.

Cho, Y. H., \& Lee, J.-H. (2018). Entrepreneurial orientation, entrepreneurial education and performance. Asia Pacific Journal of Innovation and Entrepreneurship, 12(2), 124-134. https://doi.org/10.1108/ apjie-05-2018-0028.

Choi, N., \& Majumdar, S. (2014). Social entrepreneurship as an essentially contested concept : Opening a new avenue for systematic future research. Journal of Business Venturing, 29(3), 363-376. https:// doi.org/10.1016/j.jbusvent.2013.05.001.

Codogni, M., Duda, J., \& Kusa, R. (2020). Entrepreneurial orientation : Is it subjective belief, or objective behavior. In AGH University of Science and Technology (Ed.), Functioning and Development of Enterprises - Contemporary Challenges (pp. 9-17). AGH University of Science and Technology Press.

Coombes, S. M. T., Morris, M. H., Allen, J. A., \& Webb, J. W. (2011). Behavioral orientations of nonprofit boards as a factor in entrepreneurial performance : Does governance matter? Journal of Management Studies, (June). https://doi.org/10.1111/j.1467-6486.2010.00956.x.

Corsini, F., Rizzi, F., \& Frey, M. (2018). Institutional legitimacy of non-profit innovation facilitators: Strategic postures in regulated environments. Technology in Society, 53, 69-78. https://doi.org/10. 1016/j.techsoc.2018.01.002.

Covin, J. G., \& Slevin, D. P. (1989). Strategic management of small firms in hostile and benign environments. Strategic Management Journal, 10(1), 75-87. https://doi.org/10.1002/smj.4250100107.

Dacin, P. A., Dacin, M. T., \& Matear, M. (2010). Social entrepreneurship: Why we don't need a new theory and how we move forward from here. Academy of Management Perspectives, 24(3), 37-57. https://doi.org/10.5465/amp.24.3.37.

Dees, J. G. (2001). The meanings of Social Entrepreneurship, refformated and revised version. Center for the Advancement of Social Entrepreneurship, 1-5.

do Adro, F., \& Fernandes, C. (2019). Social innovation: A systematic literature review and future agenda research. International Review on Public and Non-profit Marketing, 17(1), 23-40. https://doi.org/ 10.1007/s12208-019-00241-3.

do Adro, F., \& Leitão, J. (2020). Leadership and organizational innovation in the third sector: A systematic literature review. International Journal of Innovation Studies, 4, 51-67. https://doi.org/10. 1016/j.ijis.2020.04.001.

Dover, G., \& Lawrence, T. B. (2012). The role of power in non-profit innovation. Non-profit and Voluntary Sector Quarterly, 41(6), 991-1013. https://doi.org/10.1177/0899764011423304.

Drucker, P. (1985). Innovation and entrepreneurship. https://doi.org/10.2307/3101027.

Eichler, G. M., \& Schwarz, E. J. (2019). What sustainable development goals do social innovations address? A systematic review and content analysis of social innovation literature. Sustainability (Switzerland), 11(2). https://doi.org/10.3390/su11020522. 
Ferreira, J. J. M., Fernandes, C. I., \& Kraus, S. (2019). Entrepreneurship research: mapping intellectual structures and research trends. Review of Managerial Science. Springer Verlag. https://doi.org/10. 1007/s11846-017-0242-3.

Foroudi, P., Akarsu, T. N., Marvi, R., \& Balakrishnan, J. (2020). Intellectual evolution of social innovation : A bibliometric analysis and avenues for future research trends. Industrial Marketing Management, (February), 1-21. https://doi.org/10.1016/j.indmarman.2020.03.026.

García-flores, V., \& Martos, L. P. (2019). Innovación social: Factores claves para su desarrollo en los territorios. CIRIEC-España, Revista de Economía Pública, Social y Cooperativa, 97, 245-278. https:// doi.org/10.7203/CIRIEC-E.97.14148.

Goktan, A. B., \& Gupta, V. K. (2015). Sex, gender, and individual entrepreneurial orientation: Evidence from four countries. International Entrepreneurship and Management Journal, 11, 95-112. https:// doi.org/10.1007/s11365-013-0278-Z.

Hair, J. F., Black, B., Babin, B., Anderson, R. E., \& Tatham, R. L. (2010). Multivariate Data Analysis. (7th ed.). Pearson Prentice Hall.

Halberstadt, J., Niemand, T., Kraus, S., Rexhepi, G., Jones, P., \& Kailer, N. (2020). Social entrepreneurship orientation: Drivers of success for start-ups and established industrial firms. Industrial Marketing Management. https://doi.org/10.1016/j.indmarman.2020.06.012.

Hammerschmidt, J., Eggers, F., Kraus, S., Jones, P., \& Filser, M. (2020). Entrepreneurial orientation in sports entrepreneurship - a mixed methods analysis of professional soccer clubs in the Germanspeaking countries. International Entrepreneurship and Management Journal, 16, 839-857. https:// doi.org/10.1007/s11365-019-00594-5.

Hernández-Perlines, F., Moreno-García, J., \& Yáñez-Araque, B. (2019). The influence of socioemotional wealth in the entrepreneurial orientation of family businesses. International Entrepreneurship and Management Journal, 15, 523-544. https://doi.org/10.1007/s11365-019-00561-0.

Hong, J., \& Cho, D. (2012). The effects of market orientation, entrepreneurial orientation and social networks on the social performance of non-profit organizations. In International Conference on Human Computer Interaction (vol. 342, pp. 240-248). Springer, Heidelberg. https://doi.org/10.1007/978-3642-35270-6_33.

Jesús Rodríguez-Gulías, M., Rodeiro-Pazos, D., Fernández-López, S., Corsi, C., \& Prencipe, A. (2018). The role of venture capitalist to enhance the growth of Spanish and Italian university spin-offs. International Entrepreneurship and Management Journal, 14, 1111-1130. https://doi.org/10.1007/ s11365-017-0489-9.

José Rodríguez-Gutiérrez, M., Romero, I., \& Yu, Z. (2020). Guanxi and risk-taking propensity in Chinese immigrants' businesses. International Entrepreneurship and Management Journal, 16, 305-325. https://doi.org/10.1007/s11365-019-00566-9.

Khan, I., \& Bashir, T. (2020). Market orientation, social entrepreneurial orientation, and organizational performance : The mediating role of learning orientation. Iranian Journal of Management Studies, 13(4), 673-703. https://doi.org/10.22059/ijms.2020.289467.673800.

Kim, Lee, W., \& Choi, D. (2013). An empirical study of factors influencing performance of social enterprises in South Korea. In USABE (p. 30). San Francisco, CA.

Kim, Y. (2010). Improving performance in U. S. state governments. Public Performance \& Management Review, 34(1), 104-129. https://doi.org/10.2753/PMR1530-9576340106.

Kraus, S., Breier, M., Jones, P., \& Hughes, M. (2019). Individual entrepreneurial orientation and intrapreneurship in the public sector. International Entrepreneurship and Management Journal, 15, 12471268. https://doi.org/10.1007/s11365-019-00593-6.

Kraus, S., Niemand, T., Halberstadt, J., Shaw, E., \& Syrjä, P. (2017). Social entrepreneurship orientation : Development of a measurement scale social. International Journal of Entrepreneurial Behavior and Research, (July). https://doi.org/10.1108/IJEBR-07-2016-0206.

Kusa, R. (2016). Measuring entrepreneurial orientation in the social context. Entrepreneurial Business and Economics Review, 4(3), 117-129. https://doi.org/10.15678/EBER.2016.040309.

Lacerda, F. M., Martens, C., \& Freitas, H. M. R. (2019). Non-profit entrepreneurial orientation : A systematic literature review and conceptual framework. Non-Profit Management and Leadership, (December), 1-16. https://doi.org/10.1002/nml.21400.

Lages, M., Marques, C. S., Ferreira, J. J. M., \& Ferreira, F. A. F. (2017). Intrapreneurship and firm entrepreneurial orientation: Insights from the health care service industry. International Entrepreneurship and Management Journal, 13, 837-854. https://doi.org/10.1007/s11365-016-0428-1.

Lieberman, M. B., \& Montgomery, D. B. (1988). First-mover advantages. Strategic Management Journal, 9(Summer), 41-58. 
Ling, Y., Concepción López-Fernández, M., Serrano-Bedia, A. M., \& Kellermanns, F. W. (2020). Organizational culture and entrepreneurial orientation: Examination through a new conceptualization lens. International Entrepreneurship and Management Journal, 16, 709-737. https://doi.org/10.1007/ s11365-019-00600-w.

Llanos-Contreras, O., Alonso-Dos-Santos, M., \& Ribeiro-Soriano, D. (2020). Entrepreneurship and risktaking in a post-disaster scenario. International Entrepreneurship and Management Journal, 16, 221-237. https://doi.org/10.1007/s11365-019-00590-9.

Lumpkin, G. T., \& Dees, J. G. (2001). Linking two dimensions of entrepreneurial orientation to firm performance: The moderating role of environment and industry life cycle. Journal of Business Venturing, 16(5), 429-451. https://doi.org/10.1016/S0883-9026(00)00048-3.

Lumpkin, G. T., \& Dess, G. G. (1996). Clarifying the entrepreneurial orientation construct and linking it to performance. The Academy of Management Review, 21(1), 135-172.

Lumpkin, G. T., Moss, T., Gras, D., Kato, S., \& Amezcua, A. (2013). Entrepreneurial processes in social contexts: How are they different, if at all? Small Business Economics, 40(3), 761-783.

Lurtz, K., \& Kreutzer, K. (2017). Entrepreneurial Orientation and social value creation in non-profit organizations: The pivotal role of social risk-taking and collaboration. Non-Profit and Voluntary Sector Quarterly, 46(1), 92-115. https://doi.org/10.1177/0899764016654221.

Marques, C. S., Marques, C. P., Ferreira, J. J. M., \& Ferreira, F. A. F. (2019). Effects of traits, selfmotivation and managerial skills on nursing intrapreneurship. International Entrepreneurship and Management Journal, 15, 733-748. https://doi.org/10.1007/s11365-018-0520-9.

Martens, C. D. P., Lacerda, F. M., Belfort, A. C., \& de Freitas, H. M. R. (2016). Research on entrepreneurial orientation: Current status and future agenda. International Journal of Entrepreneurial Behavior and Research, 22(4), 1-28. https://doi.org/10.1108/IJEBR-08-2015-0183.

Mendes, A. (2018). Importância Económica e Social das IPSS em Portugal.

Migliori, S., Pittino, D., Consorti, A., \& Lucianetti, L. (2019). The relationship between entrepreneurial orientation, market orientation and performance in university spin-offs. International Entrepreneurship and Management Journal, 15, 793-814. https://doi.org/10.1007/s11365-017-0488-x.

Miller, D. (1983). The correlates of entrepreneurship in three types of firms. Management Science, 29(7), $770-792$.

Miller, D. (2011). Miller (1983) revisited: A reflection on EO research and some suggestions for the future. Entrepreneurship and Theory Practice, 1983, 873-894. https://doi.org/10.1111/j.1540-6520. 2011.00457.x.

Mintzberg, H. (1996). Managing government, governing management. Harvard Business Review, (MayJune), 75-86.

Morris, M. H., Webb, J. W., \& Franklin, R. J. (2011). Understanding the manifestation of entrepreneurial orientation in the nonprofit context. Entrepreneurship and Theory Practice, 405, 947-971. https:// doi.org/10.1111/j.1540-6520.2011.00453.x.

Nandan, M., Singh, A., \& Mandayam, G. (2019). Social value creation and social innovation by human service professionals: Evidence from Missouri, USA. Administrative Sciences, 9(4), 1-22. https:// doi.org/10.3390/admsci9040086.

Nuñez-Pomar, J. M., Escamilla-Fajardo, P., \& Prado-Gascó, V. (2020). Relationship between entrepreneurial orientation and social performance in Spanish sports clubs. The effect of the type of funding and the level of competition. International Entrepreneurship and Management Journal. https://doi. org/10.1007/s11365-020-00660-3.

Pearce, J. A., Fritz, D. A., \& Davis, P. S. (2010). Entrepreneurial Orientation and the Performance of Religious Congregations as Predicted by Rational Choice Theory. Entrepreneurship and Theory Practice, (January). https://doi.org/10.1111/j.1540-6520.2009.00315.x.

Pellegrini, M. M., Rialti, R., Marzi, G., \& Caputo, A. (2020). Sport entrepreneurship: A synthesis of existing literature and future perspectives. International Entrepreneurship and Management Journal, 16, 795-826. https://doi.org/10.1007/s11365-020-00650-5.

Piccarozzi, M. (2017). Does social innovation contribute to sustainability? The case of italian innovative start-ups. Sustainability (Switzerland), 9(12), 1-28. https://doi.org/10.3390/su9122376.

Pinheiro, P., Daniel, A., \& Moreira, A. (2020). Social enterprise performance : The role of market and social entrepreneurship orientations. Voluntas. https://doi.org/10.1007/s11266-020-00266-x.

Presidência do Conselho de Ministros (1997). Resolução do Conselho de Ministros nº197/97. Retrieved December 4, 2020, from https://data.dre.pt/eli/resolconsmin/197/1997/11/18/p/dre/pt/html. 
Rauch, A., Wiklund, J., Lumpkin, G. T., \& Frese, M. (2009). Entrepreneurial Orientation and Business Performance: An Assessment of Past Research and Suggestions for the Future. Entrepreneurship and Theory Practice, (May). https://doi.org/10.1111/j.1540-6520.2009.00308.x.

Roque, Â., \& Rocha, P. (2019). Presidente da CNIS . "Vou exigir que haja uma compensação para atualização do salário mínimo." Renascenca, pp. 2-8. Retrieved from https://rr.sapo.pt/2019/11/22/relig iao/presidente-da-cnis-vou-exigir-que-haja-uma-compensacao-para-atualizacao-do-salario-minimo/ noticia/172577/.

Ruano, A. J. M., Manso, J. R. P., De Pablo Valenciano, J., \& Rumí, M. E. M. (2020). The misericórdias as social economy entities in Portugal and Spain. Religions, 11(4:200), 1-24. https://doi.org/10. 3390/rel11040200.

Santos, G., Marques, C. S., \& Ferreira, J. J. M. (2018). What are the antecedents of women's entrepreneurial orientation? International Entrepreneurship and Management Journal, 14, 807-821. https:// doi.org/10.1007/s11365-017-0481-4.

Sanzo, M. J., Álvarez, L. I., Rey, M., \& García, N. (2015). Business - non-profit partnerships: Do their effects extend beyond the charitable donor-recipient model? Non-Profit and Voluntary Sector Quarterly, 44(2), 379-400. https://doi.org/10.1177/0899764013517770.

Schumpeter, J. (1934). The theory of economic development. Harvard University Press.

Schumpeter, J. (1939). Business Cycles: a theorical, historical, and statistical analysis of the capitalist process. (McGraw-Hill Book Company Inc., Ed.).

Schumpeter, J. (1942). Capitalism, Socialism and Democracy. (G. A. \& Unwin, Ed.).

Starnawska, M. (2017). Revising entrepreneurial orientation construct in a social enterprise. In Business and Non-Profit Organizations Facing Increased Competition and Growing Customers' Demands (Vol. 16, pp. 19-20). Tomaszowice.

Suh, J., Harrington, J., \& Goodman, D. (2018). Understanding the link between organizational communication and innovation: An examination of public, non-profit and for-profit organizations in South Korea. Public Personnel Management, 47(2), 217-244. https://doi.org/10.1177/009910260187609 30 .

Sullivan Mort, G., Weerawardena, J., \& Carnegie, K. (2003). Social entrepreneurship: Towards conceptualisation. International Journal of Non-profit and Voluntary Sector Marketing, 8(1), 76-88. https:// doi.org/10.1002/nvsm.202.

Syrjä, P., Puumalainen, K., Sjögrén, H., Soininen, J., \& Durst, S. (2019). Entrepreneurial orientation in firms with a social mission - a mixed-methods approach. Cogent Business and Management, 6(1). https://doi.org/10.1080/23311975.2019.1602016.

Tan, W., \& Yoo, S. (2015). Social entrepreneurship intentions of non-profit organizations. Journal of Social Entrepreneurship, 6(1), 103-125. https://doi.org/10.1080/19420676.2014.954260.

Turpin, A., \& Shier, M. L. (2020). Social entrepreneurial orientation in human service organizations: A scoping review. Human Service Organizations: Management, Leadership \& Governance, 44(2), 144-168. https://doi.org/10.1080/23303131.2019.1700580.

Voss, Z. G., Voss, G. B., \& Moorman, C. (2005). An empirical examination of the complex relationships between entrepreneurial orientation and stakeholder support. European Journal of Marketing, $39(9 / 10), 1132-1150$.

Wales, W. J., Gupta, V. K., \& Mousa, F. (2011). Empirical research on entrepreneurial orientation: An assessment and suggestions for future research. International Small Business Journal, 31(4), 357381. https://doi.org/10.1177/0266242611418261.

Wales, W. J., Kraus, S., Filser, M., Stöckmann, C., \& Covin, J. G. (2020). The status quo of research on entrepreneurial orientation: Conversational landmarks and theoretical scaffolding. Journal of Business Research. https://doi.org/10.1016/j.jbusres.2020.10.046.

Zahra, S. A., Gedajlovic, E., Neubaum, D. O., \& Shulman, J. M. (2009). A typology of social entrepreneurs: Motives, search processes and ethical challenges. Journal of Business Venturing, 24(5), 519-532. https://doi.org/10.1016/j.jbusvent.2008.04.007.

Publisher's Note Springer Nature remains neutral with regard to jurisdictional claims in published maps and institutional affiliations. 